\title{
The coastal military architecture of World War II in Sardinia Maddalena Mameli $^{\mathrm{a}}$, Paolo Sanjust ${ }^{\mathrm{b}}$
}

Dipartimento di Ingegneria Civile Ambientale Architettura, Cagliari, Italia, amaddalena.mameli@gmail.com, bsanjust@unica.it

\begin{abstract}
After the Unification of Italy and after the First World War, the Stato Maggiore of the Royal Italian Army had to change the defence strategies and give more attention to coastal defence, because of the changing political relations and the development of military technology. In this overall strategic framework, the island of Sardinia was considered an "outpost of Italy", because of its defensive and offensive importance in the Mediterranean Sea. During World War II coastal defence became the operational priority of the Italian Army. In Sardinia, this was crucial for its proximity to Corsica and Tunisia and as a target of the Allies (after 1943). Consequently, substantial defence forces were introduced: army corps, brigades, mobile divisions, assault guns and gun trucks. The Army started to erect permanent fortification, in particular reinforced concrete structures produced designed according to standardized modules but adapted to the context using the means, resources and techniques available.

Along the Sardinian coast, hundreds of bunkers were built and most of them are still existing in a state of neglect, sometimes in contexts of particular of great landscape and environmental value. This paper presents the systematic study of these "modern ruins built in concrete", through the examination of documents found in historical military archives and through a direct investigation of some of the most significant works. Also it offers a cataloguing through the categories of different disciplines (history, architecture, engineering, "Art of War" and ballistics) to encourage their enhancement and conservation, as architectural expression of a particular period of the 20th century history.
\end{abstract}

Keywords: fortifications, bunkers, Sardinia, Mediterranean.

\section{Introduction}

Following the unification of Italy (17 March 1861) several fortification plans were drawn up for the protection of the national territory: (1871) First General Plan of Fortifications, (1874) Second General Plan of Fortifications, (1882) General Plan of Fortifications: defence of the Alps area and coastal defence limited to the ports (Grioni, Carro, 2013).

Following WWI, with the changes in political relations and the development of military technology, the Stato Maggiore of the Royal Army (SMRE) was compelled to modify its defensive strategies and dedicate greater attention to coastal defence. Already starting from 1924 plans were launched for the construction of bases and naval support structures at Genoa, La Spezia, Livorno, Elba-Piombino, in the Riviera di Ponente, at Civitavecchia and Napoli, in Sicily and Sardinia (Boglione, 2012).

As indicated in the Memoria riassuntiva circa le difese della Sardegna, the island was considered on the global strategic map as an 'outpost of Italy'. As international relations grew more strained, in 1931, another document, Istruzione per la difesa delle coste stimulated creation of a major plan for the strengthening of Sardinia's coastal defences (Grioni, Carro, 2013). 
During WWII, defence of Italy's coastline became one top priority of the Italian Armed Forces. The Stato Maggiore of the Army adopted several measures and actions to upgrade defence.

Sardinia was especially important because of its strategic location at the centre of the Western Mediterranean sea. The permanent fortification building programme covered the whole island: the Sulcis-Iglesiente area, important for its mining industry; Cagliari and its hinterland, from Quartu Sant'Elena to Capoterra; Gallura as far as La Maddalena and the area of Olbia, linking up with the mainland; and also Porto Ferro, Porto Conte and Alghero; Porto Torres, Castelsardo and Marina di Sorso; Oristano-Mussolinia; Bosa, Santa Caterina di Pittinurri; Cala Gonone, Marina di Orosei, Santa Maria Navarrese, Arbatax and Bari Sardo, Muravera (Grioni, Carro, 2013).

In 1942 were established the Defence Works Office of the XIII Army Corps for execution of these works, which supervised the local units producing studies and technical drawings and the General Engineering Directorate.

Construction works started in 1942 in the Cagliari Sector. At the beginning of 1943 the status of the fortifications in Sardinia was as follows: 458 projects completed, 114 projects almost completed (lacking weapons and internal equipment), 76 projects in progress (laying of cement partially completed), 118 in the initial stage (excavations in progress) and just 575 designed (Boglione, 2012).

\section{Military and territorial organization}

In coastal areas, the military organisation, matched by precise territorial organisation, included: a front line consisting of naval and air forces acting offshore; a second line consisting of "containment arcs", i.e. lines of fortified strongholds with one or more structures protecting areas exposed to possible enemy landings; and a third line, or "manoeuvring mass", com- plete with artillery. Additionally, a "land front" line of defence was built, to protect urban areas.

In general, the defence used: Coastal Observation Points (POC) for ongoing surveillance; Fixed Units (NF) to repel attempted landings, subsequently transformed into cement concrete posts; anti-ship batteries with barbette mountings; anti-landing batteries sited in caves or hollows in the ground; batteries located further inland to support resistance; Strongholds; Mobile Units with fire support duties; Coastal Blocking Points (PBC) blocking roads and railways; and Manoeuvring Units to combat the enemy (Grioni, Carro, 2013).

\subsection{Military circulars}

The Stato Maggiore of the Royal Army issued guidelines on the design and construction of fortifications in the national territory by means of Military Circulars and their technical annexes. Each Army Corps interpreted the guidelines and applied them in the area under its purview.

The first official guidelines for the design of defence structures are those concerning the Vallo Alpino del Littorio, the system of fortifications ordered by Mussolini starting from 1931, to protect the Italian-French border. From then and up to 1943 , many circulars and their annexes established the system for the defence of the national territory, specifying strategies, designs and materials.

If the Circular 200 of 1931, Direttive per la organizzazione difensiva permanente in montagna, (Directives on permanent mountain defences), gave instructions for construction of the first generation of permanent fortifications in mountain areas, the Circular 2983 of 1936 Norme per la costruzione degli elementi delle sistemazioni difensive (Rules on defence constructions) distinguished fortifications into permanent (resistant to heavier attack); semi-permanent (resistant to small and medium-calibre weapons) and field fortifications (to be built as needed).

In 1938, the Circular 7000 Direttive per l'organizzazione difensiva, (Rules on the organisation of defences) introduced the installations 
consisting of simple concrete pillboxes, known as "Postazioni 7000" or "Appostamenti Pariani".

In 1939, the Circular 15000 Fortificazione permanente alle frontiere alpine (Permanent fortification of the Alpine borders) introduced the "Opere 15000", dividing them into three types (large, medium and small) based on four criteria: power (number and type of guns); protection (large, medium or small calibre); use (Command post - observation - connections); habitability and autonomy (internal equipment and stores). This Circular was supplemented in 1941 by Circular 13500 Fortificazione permanente (Permanent fortification), while the Circulars by the Engineering Arms Inspectorate, on Tipi schematici di opere (Schematic types of works) and Particolari costruttivi delle opere (Building details of works), issued in 1940 and 1942, provided drawings and technical specifications.

Finally the Circular 3 C.S.M. of 1941: Difesa delle Frontiere Marittime (Defence of coastal borders), Circular 28000 of 1941: Lavori di fortificazione alle frontiere marittime (Fortification works at the coastal borders) and the Circular 8500 , all issued by the General Staff of the Royal Army, sets out detailed criteria for the organisation and realization of coastal defences (Bernasconi, Muran, 2009; Boglione, 2012; Grioni, Carro, 2013).

\subsection{Technical Memorandum}

The first technical and operational instructions for the construction of reinforced cement concrete structures were issued in July 1934 in the Memoria tecnica dei lavori di fortificazione permanente (Technical Memorandum on permanent fortification works) written by the Ministry of War. This document provided details as to:

- components: slow-setting binding agents with constant, homogeneous composition and good curing performance of the Portland type; clean sand, free from foreign matter; river or stream sand, from quarries, or better still that obtained from the crushing of crystalline rocks, compact limestone, marble, or strong fine-grain sandstone, basalt, travertine or lava; clean gravel or crushed stone, free from foreign matter; small quantities of water, preferably well water, never sea water.

- mix: dry mixing in set proportions of cement, sand and gravel or crushed stone, followed by the addition of water, and stirring until the required thickness was obtained;

- laying: the cement to be poured into ad-hoc formwork so as to obtain uniform layers, and subsequently beaten mechanically or manually until the water rises to the surface; protected with wet sacking or tarpaulins for a further 20 days to slow down the drying process and avoid cracks which would compromise its resistance; metal reinforcements were not required other than to strengthen specific points such as loopholes and access points.

- ventilation: favoured by arranging the entrance points on several levels and providing the shelters with ventilation ducts with external openings; artificial ventilation by means of external air intakes;

- masking and camouflaging of the structures (handled by the Camouflaging Unit, set up in 1935 by the Engineering Directorate) to avoid detection by the enemy: disguising, which consists in a modification of the structure in order to make it similar to other environmental features; camouflaging, that is making the object scarcely perceptible; concealment which consists in hiding the structure from sight by means of screens or shades (Boglione, 2012).

\section{Fortifications in Sardinia}

In Sardinia, the development of permanent fortifications was heavily limited by expenditure cuts caused by the autarchic regime. Therefore, the structures had to be small, of rapid execution and inexpensive. Lines of containment fortifications were built only in the most sensitive sectors and accompanied by obstacles and mine fields, while the use of iron was limited and where possible was replaced by wood. A key feature of these structures was camouflaging (Boglione, 2012). 
Through study of the archives of the Historical Office of the Stato Maggiore, Genio Militare, and thanks to recent studies by archaeologists and military historians, we can now reconstruct the picture of the fortifications in Sardinia.

In 1948, in order to assess the operational requirements concerning permanent fortifications in Sardinia, the Autonomous Sub-Directorate for Military Works in Sardinia carried out a survey on existing structures. This and other document today allows us to identify, locate and classify the structures still existing.

\subsection{Typologies and types}

The documents on Fortification Works and Military Roads in the Cagliari area and other areas of Sardinia provide: 1. An overall comprehensive picture of the location of all the fortifications in the territory of Sardinia, divided by zone and sub-zones, showing the siting of strongholds, batteries, barricades, lookout points and military roads on maps to the scale of 1:25000; 2 . The systematic classification of each defence structure by means of a description of the site, number and type of weapons, capacity in terms of men and materials, type of military resistance afforded, present use, any damage incurred and any operational requirements.

The information on "structural elements" includes a brief description and refers to the classification contained in the document Types of fortifications existing in Sardinia, a collection of technical tables with line drawings and cross sections to scale 1:50 of the standard modules of the military installations existing in Sardinia

The most widespread type is the mounted or portable machine gun post, for protection against small-arms fire. This was a pillbox constructed in concrete, made of a circular fighting room with multiple loopholes and a quadrangular vestibule with side or rear access. On two levels, it could be covered by a flat roof, domed roof, conic roof or a calotte. The thickness of the concrete (walls and dome) was established according to the strength required. These posts were known as "round, single weapon posts" or as "Inspectorate posts" because they were introduced by Circular of the Engineering Arms In- spectorate in 1942. They were called 'Pillboxes' by the British Army and were used on the English coast. One fundamental characteristic was the camouflaging obtained by re-positioning of the layer of rock or earth, the use of rocks reproducing natural outcrops, the irregular design of profiles and openings and the care paid to surrounding vegetation.

Another widespread type is the "multi-weapon" structure consisting of a single-block poligonal or quadrangular casemate with flat roof, made in concrete for protection against small and medium-calibre weapons, provided with separate posts or rooms for automatic and antitank weapons. These are intermediate types between the works structures covered by Circular 7000 and the "Small Structures" of Circolare 15000.

Apart from these two main types other defence installations are to be found on the island: posts with outdoor barbette mountings for automatic weapons and artillery pieces with two underground rooms for munitions and shelter; firing points in caves; small masonry barracks; lookout points and armoured shelters; trenches in concrete with semi-circular niches for riflemen; field posts (nowadays no longer identifiable); more complex structures such as: aircraft spotting posts with stone walls, battery posts, munitions stores, searchlight posts and anti-aircraft and anti-ship gun posts (Grioni, Carro, 2013; Belli, Monteverde, 2002).

\subsection{The area of Cagliari}

The area of Cagliari, the most important city and port on the Island, was divided into three protection sectors. The main sector, covering CagliariSelargius-Elmas had both a seaward front and a landward front. These were accompanied and strengthened to the west and the east by two further defence lines: one towards Capoterra-Villa d'Orri and the other towards Quartu-S.IsidoroSinnai, from Poetto beach to Capitana. The whole area had some 250 posts, some of which have since crumbled away or have been swallowed up by urban sprawl. But the majority are still to be seen, some dilapidated as a consequence of neglect, others re-used as shelters, 
while a few are starting to be repaired and restored since they are located in environmental heritage areas.

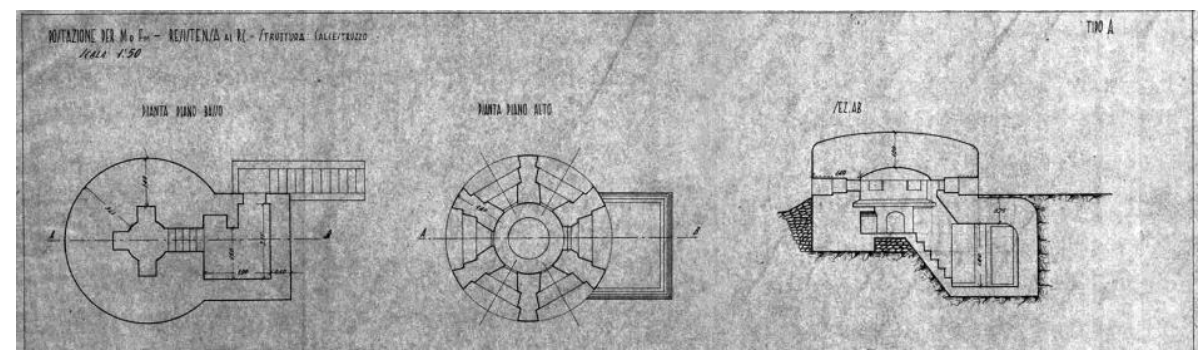

Fig. 1 - Types of fortifications existing in Sardinia

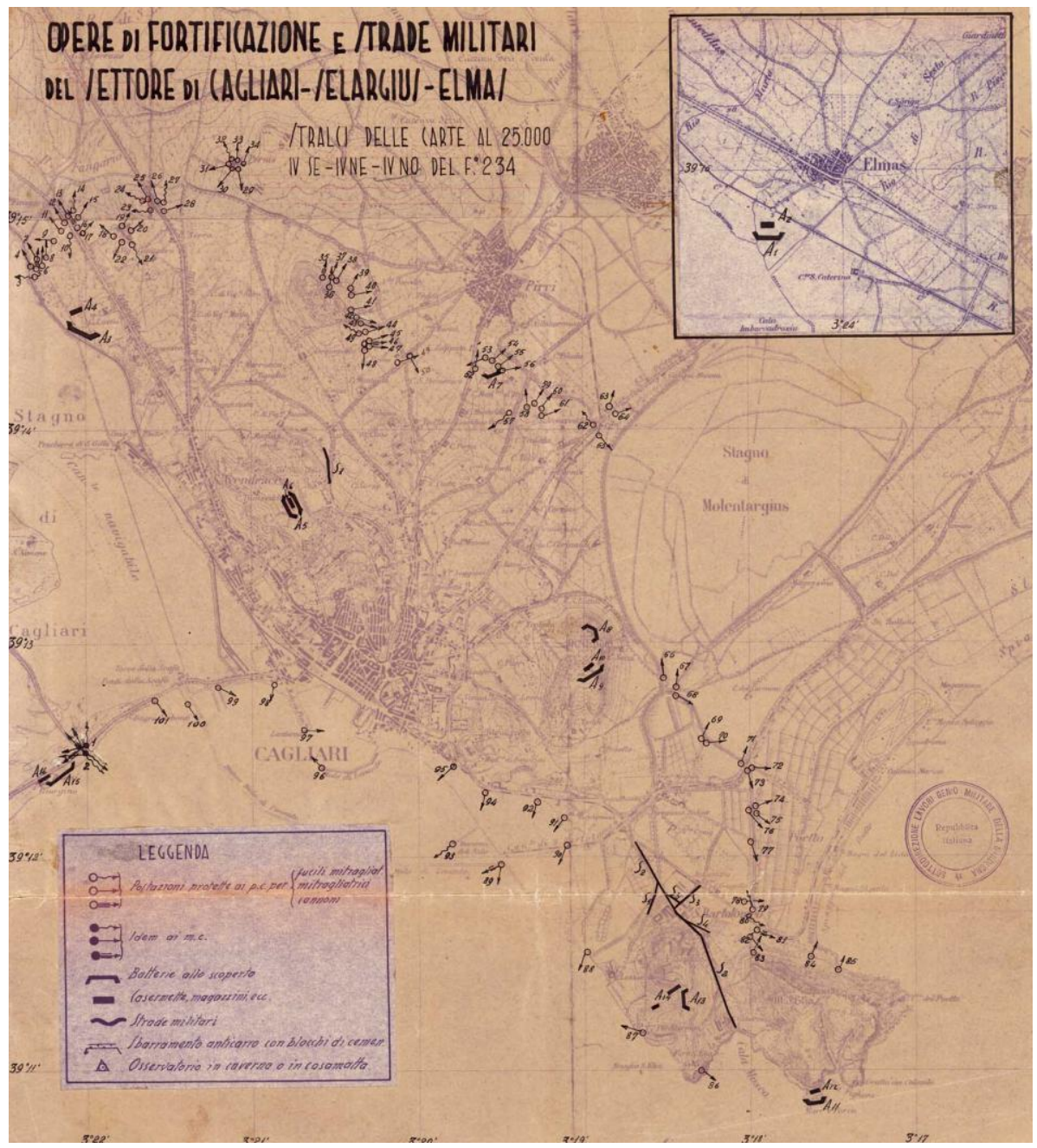

Fig. 2 - Fortification Works and Military Roads in the Cagliari area 


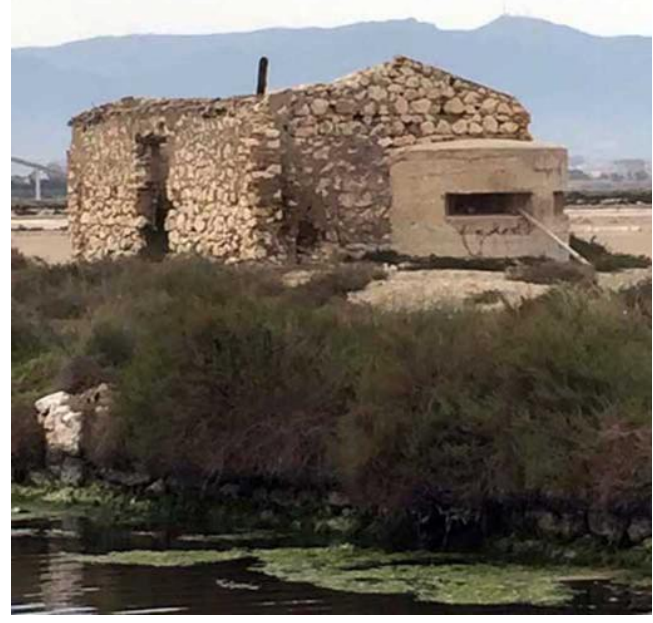

Fig. 3 and 4 - Pillboxes in Saline area in Cagliari

\section{Conclusions}

The systematic study of WW2 fortifications in Sardinia, which involved carrying out a census and classifying them on the basis of location, typologies and types, has enabled us to reconstruct their overall organisation. From a historical viewpoint, this work reconstructs the wartime effort in an important period of the $20^{\text {th }}$ century. It also gives us a picture of the organisation of the territory and of defence architecture and its presence in the landscape.

Today, having lost their original function linked to the "art of war" and seen in their schematic precise designs, these "concrete monoliths" (Virilio, 1975) reveal a distinctive character of concrete-based architecture in the first half of the 20th century as theorised by the masters of the Modern Movement, especially Le Corbusier: the importance of technique, the definition of standards, the development of standardised models which could be applied universally (Le Corbusier, 1923). But if we look at these structures carefully, considering their actual construction features and materials, we find that the ideal goal of industrialised construction methods had to come to a compromise with local situations, with the objective conditions of the historical

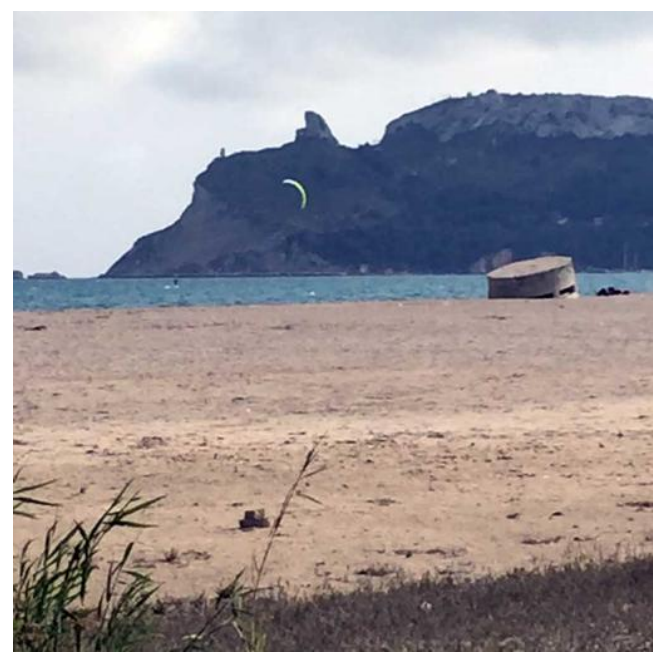

and spatial context. Structures designed according to the latest ballistic and military techniques, intended to be built in reinforced concrete with a domed or polyhedron design, were in actual fact built in non-reinforced concrete, with the addition of wooden elements and often masked by stone cladding or by vegetation which attempted to conceal their artificial nature for camouflaging purposes.

For more than 60 years these works have been silently present in our natural landscapes as small landmarks, "modern concrete ruins" (Virilio, 1975). They have often fallen prey to neglect, and at times to the "iconoclastic revenge" of the locals, who so these fortifications as "cement testimonies" (Bernasconi, Muran, 2009) to the darkest pages of the "ages of extremes" (Hobsbawm, 1994), similarly to the fortifications along the Alpine wall, the Atlantic Wall, the Maginot Line or the Mediterranean Wall in Spain (Martinez, Sanjust, 2014).

Although wars leave a hard-to-preserve heritage, through study, knowledge and restoration these structures can become elements of our cultural landscapes, our collective memory and our history (Choay, 1992). 


\section{References}

Le Corbusier (1923), Vers une architecture, Éditions Crès, Collection de "L'Esprit Nouveau", Paris. Virilio P. (1975), Bunker archéologie, Edition du Demi-Cercle, Parigi.

Choay F. (1992) Allegoria del patrimonio, Officina, Roma.

Hobsbawm E. (1994), Age of Extremes - The Short Twentieth Century 1914-1991, Joseph, London.

Sotgiu G. (1996), Storia della Sardegna dalla Grande guerra al fascismo, Laterza, Roma.

Clerici C.A. (1996), Le difese costiere italiane nelle due guerre mondiali, Albertelli, Parma.

Belli E., Monteverde A. (2002), Insediamento e difesa del territorio nella Sardegna meridionale. Ad Quartum lapidem. Atti del Convegno, Askos, Cagliari.

Kauffmann E., Jurga R. M. (2002), Fortress Europe: European Fortifications of World War II, Da Capo.

Bernasconi A., Muran G. (2009), Il testimone di cemento - Le fortificazioni del "Vallo Alpino Littorio" in Cadore, Carnia e Tarvisiano, La Nuova Base Editrice, Udine.

Aresu M., Carro G., Grioni D. (2009), Cemento Armato. Bunker archeologia nel territorio di Quartu Sant'Elena, ASSFORT Sardegna, Alisea, Cagliari.

Boglione M. (2012), L'Italia murata - Bunker, linee fortificate e sistemi difensivi dagli anni Trenta al secondo dopoguerra, Blu Edizioni, Torino, pp. 140-200.

Grioni D., Carro G. (2013), Fortini di Sardegna, 1940-1943. Storia di un patrimonio da salvaguardare, Edizioni Grafica de Parteolla, Cagliari, pp. 13-48, 111-117.

Martinez-Medina A., Sanjust P. (2014), "Muro Mediterráneo versus movimiento moderno - Mediterranean Wall versus modern architecture", in I2 - Innovación e Investigación en Arquitectura y Territorio. Revista Científica.

Cohen J. L. (2015), Architecture en Uniforme: projeter et construire pour la Seconde Guerre mondiale, Catalogue of exhibition at Centre Canadien d'Architecture of Montréal, Hazan, Paris 2011, Roma. 
